\title{
THE ASSESSMENT OF THE BAROQUE VAULT CONSTRUCTION TECHNIQUE BY SCAN-TO-BIM PROCESS: ST. BERNARD'S CHAPEL IN THE PLASY MONASTERY
}

\author{
C. Stanga ${ }^{1, *}$, H. Hasníková ${ }^{3}$, M. Previtali ${ }^{2}$, R. Brumana ${ }^{2}$, A. Grimoldi ${ }^{1}$, F. Banfi ${ }^{2}$ \\ ${ }^{1}$ Dept. of Architecture and Urban Studies, Politecnico di Milano, Milan, Italy - (alberto.grimoldi; chiara.stanga)@polimi.it \\ ${ }^{2}$ Dept. of Architecture, Build Environment and Construction Engineering, Politecnico di Milano, Milan, Italy - \\ (raffaella.brumana, fabrizio.banfi; mattia.previtali)@polimi.it \\ ${ }^{3}$ Institute of Theoretical and Applied Mechanics, Czech Academy of Sciences, Prosecká 809/76, 19000 Prague, Czech Republic - \\ hasnikova@itam.cas.cz
}

\section{Commission II, WG II/8}

KEY WORDS: Historic Building Information Modeling (HBIM), SCAN-to-BIM, Grade of Generation (GoG), Vault construction, Santini-Aichel

\begin{abstract}
:
The article focuses on the analysis of the construction technique of the star vault designed by the famous Bohemian architect from the Baroque period, Jan Blažej Santini-Aichel. The vault covers St. Bernard's Chapel in the Plasy Monastery and represents a masterpiece in Santini's late career. The authors try to understand its construction technology with the help of modern surveying methods. The shape of the vault structure is complex, therefore a detailed geometrical survey of both intrados and extrados was performed. The data collected in situ, photogrammetric blocks, were used as a basis for the modeling of the vault shape. An accurate 3D model and HBIM of the structure were generated, using a novel Scan-to-BIM process based on the integrated use of a different Grade of Generation and primitive extraction to support the modeling. This survey is part of a program to implement a vault database addressed to detect permanencies and mutations in the construction techniques across Europe, that gives back unexpected, and mostly unknown, richness of vault construction patterns.
\end{abstract}

\section{INTRODUCTION}

Thanks to the widespread use of advanced survey techniques, the realization of 3D models and HBIMs is becoming a feasible objective, changing our approach to the Built Heritage digitization (Amore, 2017). Rich detailed models are becoming an opportunity to understand complex shapes scarcely investigated in the past due to the lack of geometric information available. On the other hand, traditional survey methods (in situ analysis) are necessary particularly when the aim of the research is to understand the construction process and techniques of a historical building (Boato, 2008). Too many studies involving the analysis of vaults are limited to their geometrical aspects, without considering the relationship between geometrical design and construction techniques. However, some studies have recently addressed the topic and analysed how the shape of the vault is influenced by its construction techniques, thanks to an accurate virtual reconstruction of the vault (Brumana et al. 2018a). It is critical to deeply understand the historical building not only to appreciate the old masters' knowledge - that it is not always written in the architectural treatises - but also to have the possibility of carrying out more responsible restoration works to maximize the preservation of materials, behavior and functionalities of the old structures. In this frame, the $3 \mathrm{D}$ model is essential because it allows to virtually realize the building. Additionally, the 3D modeling opens the doors for many other possible applied domains, some more 'practical' (i.e. management of the building across the life cycle, like the LongLife Cost Management - LLCCM) and some more focused on the transmission of the history of the building for touristic purposes.

The main goal of this article is the analysis of the construction technique of the vault designed by one of the most famous
Bohemian architects from the Baroque period, Jan Blažej Santini-Aichel (1677-1723). The vault covers St. Bernard's Chapel in the Plasy Monastery, which is situated close to Pilsen in the Czech Republic and represents a masterpiece in Santini's late career. The shape of the vault is the common Santini's star vault, made of one sphere interpenetrated by lunettes, but the detailed construction and 3D modeling analysis shows the complexity of the structure, for which intrados and extrados seem to belong to different vaults (Fig. 1). Furthermore, the interesting case study allows testing the possibilities offered by advanced modeling technology in the assessment of the vault construction technique.

The goals of the research are:

- To perform a detailed geometrical survey of the vault, that does not exist yet (e.g. different curvatures, the interpenetration of solids - spherical vault and lunettes);

- To understand the construction technique of the vault (e.g. use of scaffoldings, formworks, the arrangement of the bricks, the structural behaviour);

- To understand how the proper shape of the structure was controlled in the past during construction (Santini is well known for his devotion to the geometrical shapes and theoretical rules);

- To find a balance between the geometric complexity of the vaults, the data acquired and the $3 \mathrm{D}$ representations.

In order to assess the vault construction, the approach included several steps: on-site visits, a photogrammetric survey, the generation of a 3D model, and historical building information modeling (HBIM). The basis for the 3D model was the photogrammetric survey, which was performed for both the intrados and extrados of the vault. The accurate 3D model of the structure and HBIM were generated using a novel Scanto-BIM process, based on the integrated use of different Grade

\footnotetext{
* Corresponding author
} 
of Generations - GoGs (Banfi, 2017), to show the level of complexity of the vault. In particular, the exact geometry of the structure was reached by the application of GoG 9 and GoG 10 to the post-processed point cloud obtained from the photogrammetry. The GoGs have facilitated the assessment of the curvatures of the vault or its hypothetical deflection with a high Grade of Accuracy (GoA) compared to the original data from the survey.
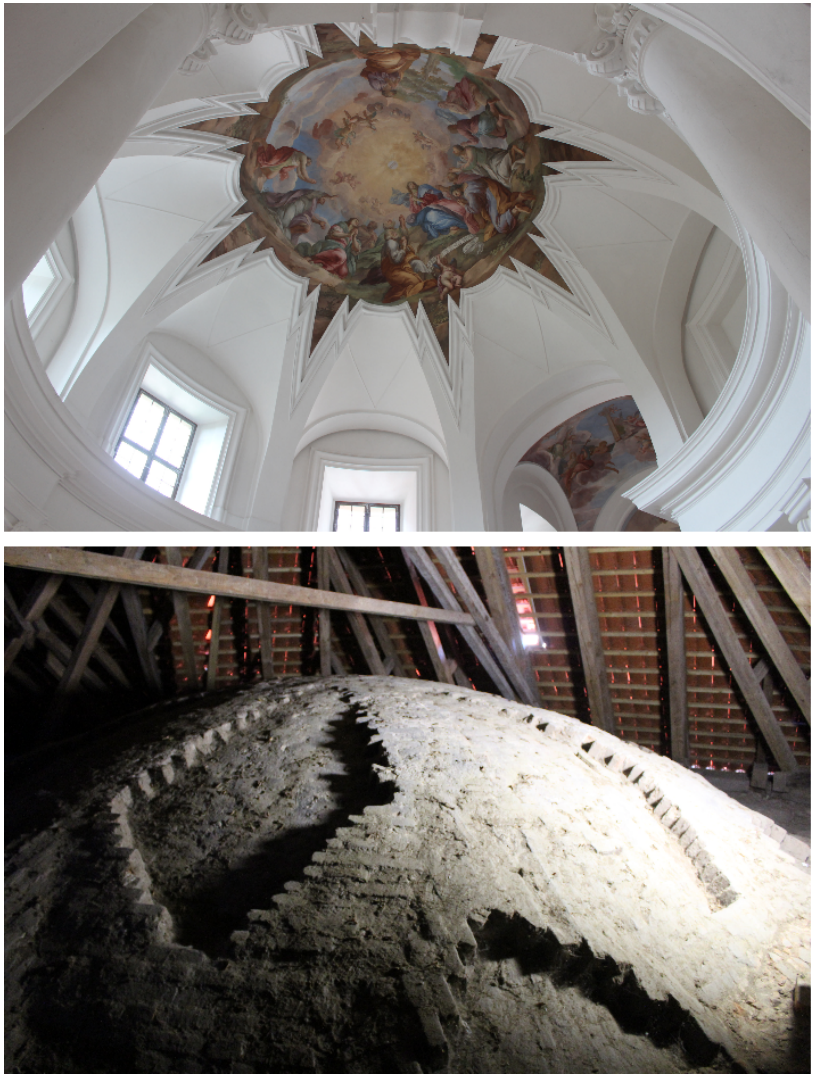

Figure 1. The intrados (top) and extrados (bottom) of the star vault covering the St. Bernard's Chapel in the Plasy Monastery

\section{RELATED WORKS}

The publications about HBIMs or BIM applied to existing buildings (concerning data capture, 3D modeling and data exchange) has highly increased in recent years (López et al., 2018). Many of them are on how to model the 'irregular' historic architectural elements and creating libraries for the Built Heritage. Furthermore, 3D modeling has been the vehicle to manage its geometrical complexity (Tucci et al., 2017).

Regarding the vaulted systems, 3D has been used to perform geometrical analysis of their genesis and shape. Some studies have used photogrammetry to gain the point clouds for the creation of $3 \mathrm{D}$ as built models of gothic vaults in Paris. They were compared with the theoretical 3D models that come from the analysis of ancient treatises on vaults construction (Capone et al., 2015). A recent study creates an HBIM Library of Renaissance domes, whose geometry is based on the geometrical rules that can be found in historical treatises (Capone et al., 2019). On the other hand, other research approaches use the 3D model to verify design hypothesis about the construction of the vault (Artese et al., 2019) or go beyond the pure geometric analysis of the vaults and try to understand how to transfer the constructive techniques to the $3 \mathrm{D}$ models. This results in an integration of the materials and constructive techniques into the HBIM, through a detailed modeling of each structural and non-structural component. In this way, HBIM family libraries are enriched with other constructive information. Furthermore, the detailed modeling helps to better understand some crucial points of the building processes (Brumana et al., 2018b; Oreni et al., 2013). Creating parametric objects in modeling heritage buildings or components, such as the vaulted elements, has its well-known challenges (Volk et al., 2014). That is why it is necessary to integrate parametric software (i.e. Revit) with generative modeling software (i.e. Rhinoceros), thus creating a parametric object that embeds the geometrical and structural properties of the original component (Banfi, 2017). The possibility offered by the georeferenced HBIM models leads to the creation of databases of constructive elements that increase knowledge sharing (Acierno, 2017; Brumana et al., 2018c).

\section{CASE STUDY}

The case study is the star vault of the Plasy Monastery, designed by Jan Blažej Santini-Aichel. Although it is a well-known construction, its $3 \mathrm{D}$ reconstruction has never been carried out.

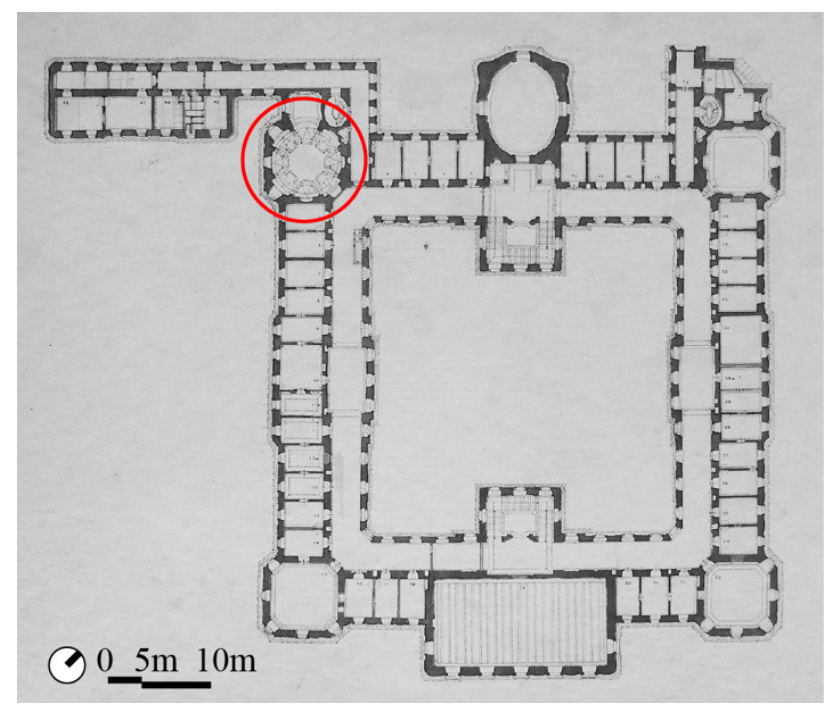

Figure 2. The plan of the Plasy Monastery, in red the St.

Bernard's Chapel (courtesy of the Plasy Monastery)

\subsection{Jan Blažej Santini-Aichel}

Jan Blažej Santini-Aichel was a Bohemian architect with Italian ancestry who became very famous for his unique style called (Czech) Baroque Gothic. The Santini family had Italian origins; Santini's grandfather Antonio, migrated from the Lugano Lake area to Prague and worked at huge building sites of the $17^{\text {th }}$ century, like the south-west extension of the Hradčany (Prague Castle) (De Meyer, 1997). It is not clear if Jan Blažej SantiniAichel was a trained architect, it seems that he was probably a painter, but with great skills in architecture. In fact, his family's work was stonemasonry (Kalina, 2010). After being trained most probably by a French architect, Jean Baptist Mathey, who gained experiences in Italy and was at the time working and living in Bohemia, Santini reached Italy through Austria. In Rome he was attracted by Francesco Borromini's dynamic Baroque style (Horyna, 1998), but he was also fascinated by the works of Guarino Guarini (Horyna, 2002), who had a great influence in the Northern Europe. Santini is known for his architectural hybridization between Gothic and Baroque forms. Kalina suggested that the 'Gothic' shapes derive from the 
tradition of the local artisans, who carried on an unbroken tradition of highly specialized labour, while the 'Baroque' ones come from the will of the powerful patrons that commissioned the works (Kalina, 2010). Santini designed many buildings in Bohemia during his career. However, his authorship is not always proven due to the lack of original documentation. Furthermore, Kilián Ignác Dientzenhofer sometimes worked on Santini's building sites after his death, like in Plasy, where he built the oval chapel of St. Benedikt. That is why sometimes the two authorships are mixed up.

\subsection{The star vault of the St. Bernard's Chapel}

The Cistercian Monastery in Plasy was founded in $12^{\text {th }}$ century. It was built on water-land on 5100 oak piles, which reinforced the swampy ground. The level of ground water is still maintained by a sophisticated water system. The architects Mathey, master of Santini, and mainly Santini himself magnificently rebuilt the convent in the Baroque style in the early $18^{\text {th }}$ century (1711-1740). The monastery abbot hired other artists to work for the monastery, e.g. Jakub Antonín Pink (1690-1748) who painted the fresco in the St. Bernard's Chapel in 1724. As mentioned before, after Santini's death, another famous Bohemian Baroque architect, Kilián Ignác Dientzenhofer, the son of Christoph Dientzenhofer, finished the convent following the original design. The St. Bernard's Chapel in the Plasy Monastery is one of Santini's masterpieces. Although it is well-known, a detailed geometrical survey of the vault and the analysis of the construction technique are still missing. A laser scanning survey in the past was performed, but only for the intrados to define the floorplan geometry and confirm Santini's authorship as the architect who was able to design in a "guarinistic" way (Pavlík, 2008), following the theoretical description and practical realization of complex vaulted systems of architect Guarini (Guarini, 1737). The chapel was designed together with the whole convent between 1707 and 1710 and was finished while Santini was still alive. The space is very light and monumental; it used to serve as a meditation room for the monks. A massive cornice emphasizes the cylindrical shape of the chapel, see Fig. 1 (Pavelka, 2017).

Also the St. Benedikt's Chapel in the Plasy Monastery was designed by Santini. Unfortunately, he died before the construction, therefore K. I. Dientzenhoffer finished the chapel respecting the "guarinistic" ideas in the oval floorplan, see Fig. 2 (Pavlík, 1997). The shape of the vault structure covering the space in the St. Bernard's Chapel is complex. Santini's designs are unique, always created for a specific purpose with a lot of symbolic signs referring to the saints, to whom the sacral objects are dedicated. Therefore, it is sometimes difficult to use the basic vault terminology. From the intrados, the shape emphasized by the central painting represents a star vault typical of Santini, but the brick arrangement of the extrados allows characterizing it as a cupola with lunettes (Škabrada, 2007).

\section{SCAN-TO-HBIM WORKFLOW}

The digital workflow includes four steps: the in situ observation; the photogrammetric survey, the modeling of the vault in NURBs-based software (Rhinoceros) and the parametrization into Revit.

\subsection{In situ observation}

During the on-site visits many data, such as the vault overall dimensions and structure, brick dimensions and arrangements, were collected. At the beginning of the study, it was believed that the eight ribs at the intrados matched the eight ribs at the extrados (Fig. 3). Further along in the analysis, the comparison between the intrados and the extrados showed a different result: the extrados ribs start from the central part, dividing the lunettes penetrating the sphere, and run down along the edges of the lunettes. The extrados ribs shape can be described as an "inverted Y", resulting in a rhomboidal arrangement. They are included in the central painted circle visible at the intrados. On the other hand, the ribs of the intrados belong to the same surface of the painted central part.

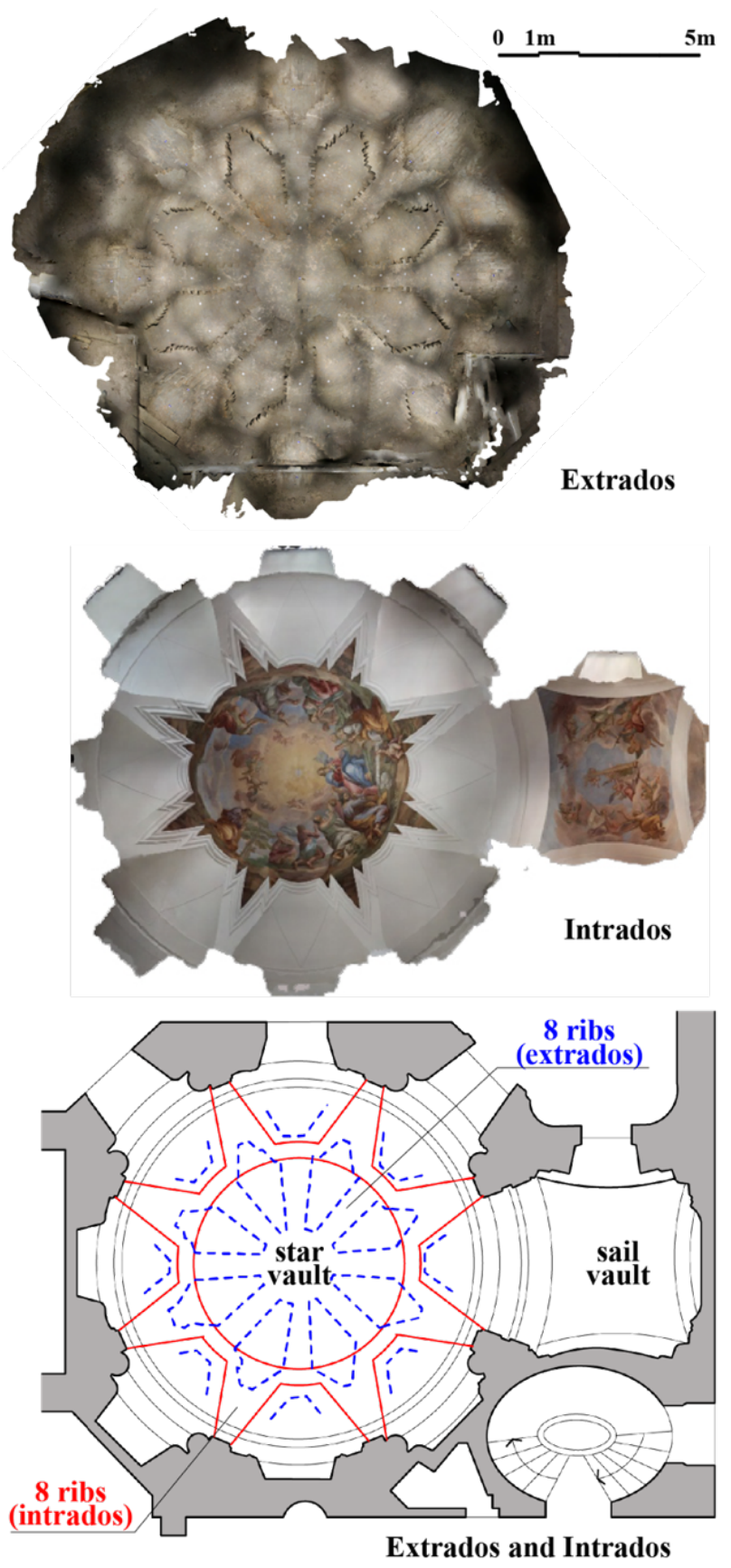

Figure 3. Top: orthomosaic of the chapel extrados. To be noticed the 'inverted Y' ribs and their rhomboidal configuration. Middle: orthomosaic of the chapel intrados. To

be noticed the star design. Bottom: The drawing of the overlapping intrados (red) and extrados (blu) of St. Bernard's chapel vault 
The bricks in the central part of the vault are arranged along concentric lines and the bricks in the lunettes are laid along their axes. The two directions meet in the ribs, where the bricks make a $90^{\circ}$ angle: see the drawing of the overlapping intrados and extrados structures (Fig. 3), where the blue represents the extrados ribs and the red the intrados ones. The thickness of the top part of this kind of vaults is usually ca $17 \mathrm{~cm}$ ("one and half of a brick"), according to other similar structures in Bohemia (Škabrada, 2007). The bricks of the extrados have different dimensions, which probably means that during the construction process of the vault old bricks coming from the medieval monastery were re-used. On top of the bricks some small local stones were used in the lunettes to 'close' the vault on the top.

\subsection{Photogrammetry}

In the St. Bernard's Chapel two cameras were used to acquire the data for photogrammetric reconstruction. The picture dataset of the intrados was acquired with a Canon EOS 600D camera, with a focal length of $45 \mathrm{~mm}$, placed on the rectangular grid of $400 \times 750 \mathrm{~mm}$ covering the circular floorplan. In this case, the camera was placed parallel to the ground and pictures were taken all the way up (zenith). The other images were taken from the circle perimeter to properly capture the lunettes and the windows above the cornice. Overall, a set of 171 pictures was acquired for the intrados (terrain pixel $2 \div 3 \mathrm{~mm}$ )

The dataset of the extrados part was made with a Canon EOS1D Mark IV camera, with a focal length of $20 \mathrm{~mm}$, stabilized on a tripod. The vault surface had to be cleaned from the dust so that the desired brick texture was visible, although it was partially covered with a thin layer of plaster. A target grid (black and white checkerboards) was installed on the extrados, placed according to the vault geometry. This was done to ensure alignment when processing the pictures, especially for the areas with less contrast between bricks and mortar courses. The targets were placed all along the surfaces of the ' $\mathrm{Y}$ '-shaped ribs, on the webbings that are in between the ribs, and on the lunettes. The photogrammetric block of the extrados comprises 583 pictures (terrain pixel $1 \div 3 \mathrm{~mm}$ ). Additionally, a geometrical survey of the vault was carried out and the following data were acquired through laser measurement and trilateration: the diameter of the chapel, the height of the ceiling top for the intrados, the dimension of the bricks, and the webbings for the extrados. A further TLS campaign is planned for the summer 2019 in order to verify the thickness of the vault (now derived by direct survey). It will be then compared to the images acquired with IRT thermal survey to better detect the bricks arrangement along the intrados vault springer, which is currently not detectable from the extrados due to the filling material, usually adopted to stabilize the vault along the border of the abutments. Then, TLS survey will provide a reliable source to understand the geometric issues that are related to the generation of orthomosaics (Barazzetti et al., 2007).

Agisoft PhotoScan Pro software was used to process the photogrammetric blocks. The datasets have been the basis for the realization of the $3 \mathrm{D}$ orthomosaics, which are necessary for the material and decay analysis (cracks, imprints after water leakage, etc.), and for the point clouds that were used to generate the 3D model of the vault. Point clouds, both from laser scanning and photogrammetry, are the first step into the Scan-to-BIM process.

\subsection{Modeling the vault geometry and generating objects}

One of the main objectives of this research was to create an information system, integrating different types of data (3D survey, point cloud, historical documentation, geometric analysis) and improving the sharing of information between the involved users. During the task, several advanced modeling techniques were applied to generate complex elements from point clouds.

The generative process of the case study is based on four modeling steps:

- post processing: cleaning of point clouds to identify the main geometric discontinuities (i);

- generative modeling: applications of new Grade of Generation (GoG 9 and 10) to transform point clouds into detailed NURBs models (ii);

- HBIM generation: transformations of the NURBs model into a parametric model (iii);

- BIM orientation (iv): sharing of the information model on a BIM cloud and database.

The first post-processing phase required the identification of the main lines of discontinuity of the vault. Thanks to the use of Autodesk Recap software, it was possible to import the point clouds into Mc Neel Rhinoceros. The point clouds were divided in different layers, favoring the geometric analysis and the identification of the main geometric discontinuities.

STEP 1 - POST PROCESSING : POINT CLOUDS LAYERS
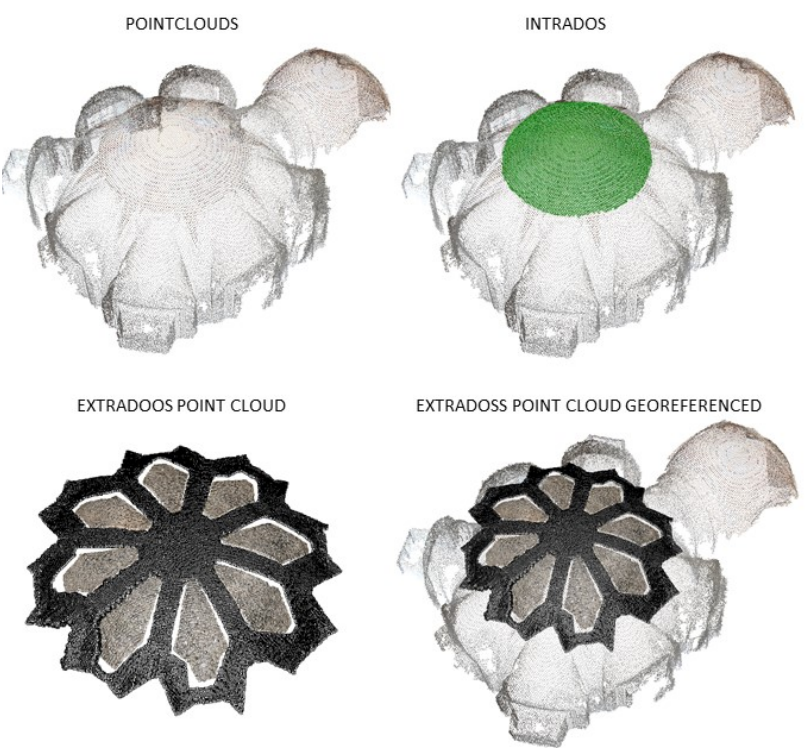

STEP 2 - GENERATIVE MODELING
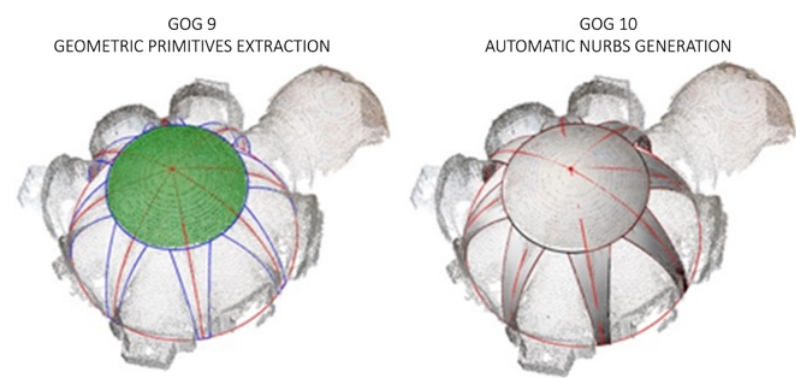

Figure 5. Step 1 - Post processing: Point clouds layers allowed the identification of external and internal edges; Step 2 Generative modeling: GoG 9 and 10

The second phase required the integrated use of two new Grades of Generation (GoG 9 and 10). In particular, the application of the GoG 9 allowed the extraction of geometric primitives 
corresponding to the external and internal edges of each individual structural element. On the other hand, GoG 10 allowed the automatic generation of complex surfaces corresponding to the internal points of the cloud. Figures 5 shows the steps listed above and the grade of accuracy achieved for the main part of the vault. The accuracy of the 3D model compared to the original dataset (i.e Point Clouds) is a necessary parameter that allows to verify the quality of the postprocessing workflow. The literature has already focused on this topic and offers different solutions (Besl et al. 1992; Lague et al., 2013), but in this case, a specific procedure was applied: the Automatic Verification System (AVS) (Banfi et al., 2018). Through this, it has been possible to check the standard deviation between model and point clouds. The GoA achieved was $1 \mathrm{~mm}$ (Fig. 6) (Banfi 2019).

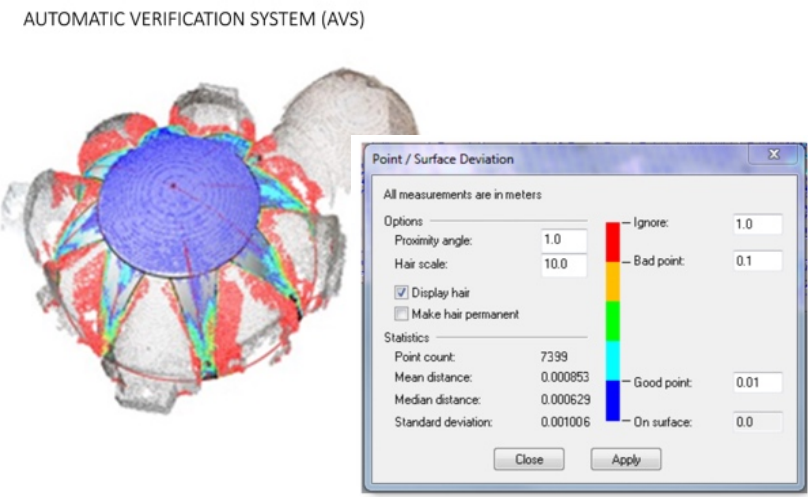

GRADE OF ACCURACY (GOA) - STANDARD DEVIATION

Figure 6. NURBs model with a GoA of $1 \mathrm{~mm}$

When the vault reconstruction by NURBs surfaces was finished, the geometry itself in the form of .sat files was imported into a BIM software (third step - Fig. 7). In this case, the parametric software Autodesk Revit was used, where the data collected during the study were stored in an information "database". HBIM is an ideal way to have both the shape and information presented together, linking the modelled object to external databases (e.g. pictures, mesh models of the room equipment, information pages, digital archives). This is of primary importance because of the possibility of sharing the constructive knowledge through databases.

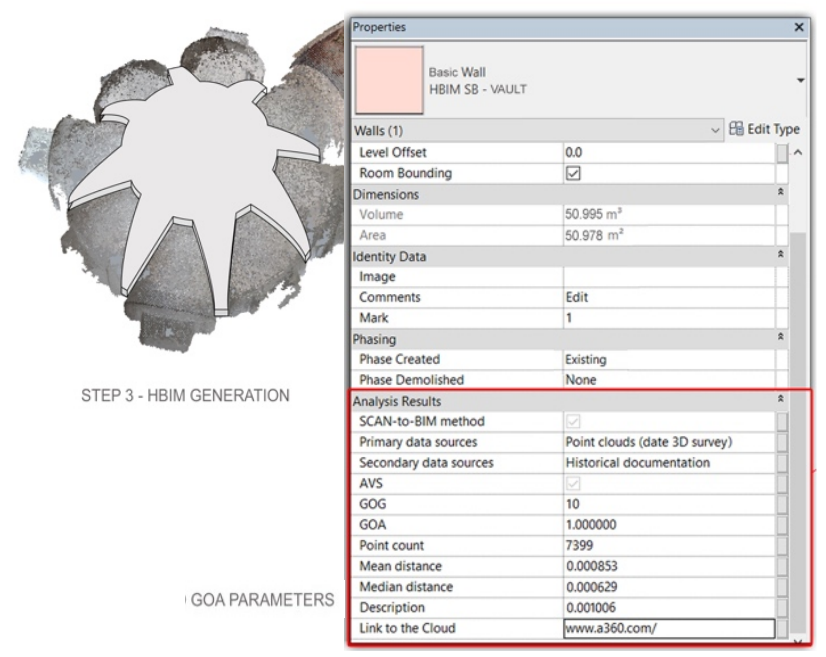

Figure 7. Step - 3 HBIM generation: transformations of the NURBs model into a parametric model

\section{CONNECTION WITH OTHER BOHEMIAN AND ITALIAN VAULTED SYSTEMS}

Some common features, in terms of vault shape and construction techniques, can be found in other Bohemian structures by Santini, such as the Church of St. John of Nepomuk or the chapel in Smirice. In Italy, the vault that covers the oval space in the Cattaneo Palace in Cremona recalls some construction features of the St. Bernard's Chapel in the Plasy Monastery (Fig. 8).

\subsection{St. John Nepomuk at Zelená Hora}

The Church of St. John Nepomuk at Zelená Hora (meaning green mountain) is Santini's most famous work, listed in the UNESCO World Heritage Sites. The church has a unique design and is full of symbols, e.g. the tongue in the center of the ceiling revokes St. John's legend, or the recurrence of the number five in the building. The church was exceptional at the time and its style isn't simply classifiable: it is Santini's synthesis of the Gothic architecture and his take on the Italian Baroque (Horyna, 2008). The pilgrimage church was initiated by the abbot of the Cistercian monastery in Žd'ár nad Sázavou, Václav Vejmluva, who commissioned the work to Santini. The church was built in 1719-22, more or less in the same timeframe as the Plasy one. In 1784 a great fire destroyed the roof of the church, which was later restored, but it cannot be excluded that the vault was rebuilt as well.

The vault that covers the church is close to the Plasy design. It reminds of a star vault, but it is a cupola with lunettes. However, the lunettes are more widely spaced than in Plasy. Up to now it was not possible to find construction studies on the vault, but only an analysis of its original decoration (Zastoupil et al., 2011). Its extrados seems to have the same construction techniques with the ribs as in Plasy, although without the ' $Y$ ribs' configuration (Štíchová, 2008, p. 65).

\subsection{Chapel of the Epiphany of Our Lord in Smiřice}

The research group, that did the detailed geometrical analysis of the floorplan based on laser scanning data at the Plasy monastery, did the same for the chapel of the Epiphany of Our Lord in Smiřice. The authorship of the design is still unknown. Norber-Schulz proposed C. Dientzenhofer as the author of the chapel, but according to recent analysis, Santini could be the architect due to its design, which is close to the one of the architect Guarini, who strongly influenced the architecture in Northern Europe (Bohemia and German countries) (Pavlík et al., 2013). In the chapel of Smirice, the architect tried to match Guarini's principles with the middle-European system of mural pillars. The plan is inspired by the St. Lawrence church in Turin and by Hildebrandt's church in Gabel (Norber-Schulz, 1968).

According to the decoration dating, the vault was built around 1706 (Pavlík et al., 2013). It is a very flat brick vault that seems generated by a skene cupola interpenetrated by sail-vault lunettes. The latters are different from the lunettes in Plasy and Zelená Hora. On the other hand, the vault leans on supports which makes it comparable with the two vaults.

\subsection{Cattaneo Palace in Cremona}

The oval room of the Cattaneo Palace is probably part of the great renovation of the building, started around the second half of the $18^{\text {th }}$ century and commissioned by the marquise Antonio Cattaneo to the architect Faustino Rodi (Grimoldi, 2005). Although the shape of the vault is different, it has some features in common with the other ones mentioned above. It presents the 
same construction elements, such as the Telamons, see Fig. 8, which hide the arches that support the oval central cupola, and the ribs on the extrados.

\subsection{St. Bernard's Chapel construction process}

The construction of the St. Bernard's vault components (lunettes, ribs, central vault) happened simultaneously: the lunettes were built first, starting from the perimeter of the chapel, then they grow up together with the ribs and the central part, using main arch centerings for the ribs and light centerings for the central part. At the beginning of the study, it had been hard to understand if the lunettes interpenetrated with the sphere in the same plane or if there was a step in between them, but the detailed analysis of the shape of the vault webbings and the ribs confirmed the way they were joined in the construction process: some bricks of the ribs are placed as header and are connected with the main vault. Tie rods, that are commonly found in vault constructions, were probably not necessary because of the shape of the vault. Indeed, the structural behavior of a vault depends not only on stiffening devices, i.e. metal or wood tie rods, but also on its shape and on the arrangements of the bricks (Etlin, 2015). In particular, it is important to 'give a direction' to the thrust of the vault, in this case, for example, with the position of the ribs. All the vaults mentioned in this study have ribs that bring the thrust of the vault down on the arch supports.

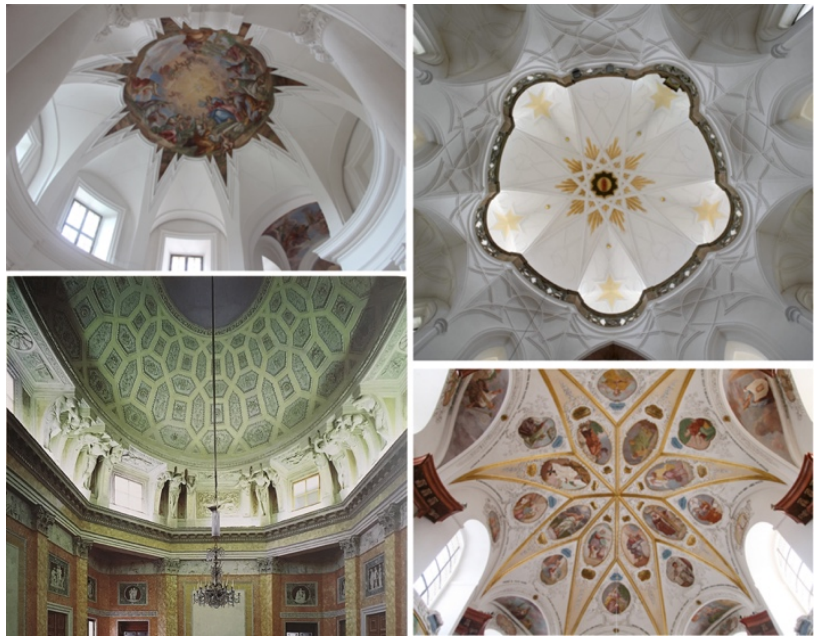

Figure 8. Examples of star vaults - St. Bernard's Chapel (CZ, top left), Church of St. John Nepomuk (CZ, by Čapková, top right), Cattaneo Palace (IT, bottom left), and Chapel of the Epiphany of Our Lord (CZ, by Peška, bottom right)

\section{TOWARDS A WEB-ACCESSIBLE VAULT GEODB}

The surveying and modeling of the star vault of Plasy highlights the richness of solutions adopted in such vault constructions, the unicity and at the same time the similarities with many other vaults. Such star vaults are in fact characterized by a skeleton made of different shaped reinforced ribs and thin webbings, allowing a multiplicity of outputs, real embroideries on the mixed vault and ribs concept, generating different 'masonry needlework'. The construction knowledge of such vaulted structures mainly comes from local masonry craftmanship, which is only partially described in the architectural treatises. However, it is also influenced by skills and knowledge exchange between architects and masons who travelled throughout different countries. Nowadays, the possibility to interconnect all the information coming from the different case studies can show how families of workers across Europe (Della Torre, 1997; Mutschlechner, 1990) shared experiences and know-how in the design and construction of vaulted systems. Furthermore, the low cost and speed of advanced surveying techniques, together with the GEODB virtual hubs, allow to acquire data in a massive way and to compare vaulted systems across time and space (Brumana et al., 2018b; Stanga et al., 2019). The availability of Virtual Hubs technologies (Mazzetti, et al., 2017) supporting semantic, geographic and temporal queries on the Open Data (including Geographic Open Data) has been used to build a web-accessible platform to feed all the data gathered through the surveying and qualitative analysis, together with historical information on the vaulted systems (Brumana et al. 2018b). A 'live' updatable repository that can be accessed through different queries. The database of vaulted systems does not yet allow for crowdsourcing, even if it is planned with the goal of accelerating the data acquisition process by different sources. The database allows to manage geotiff (i.e. the intrados and extrados orthophotos of each vault) related to the geographic coordinates of the buildings, and to link 3D model objects with different formats, together with free access to A360 HBIM Autodesk (C). Different information can be updated thanks to the flexibility of the DB which is generated on the input data describing the richness and peculiarity of the vaults: their own typology, their building typology, their geographic position (latitude, longitude), their constructive components (in this case, the mixed vaults and ribs components), the brick arrangements (soldier laid or in foglio, double or single layered), their historical phases, free text description, keywords, together with technical information on the surveying and diagnostic techniques, such as the scale and the accuracy of the drawings and the 3D models, and IRT thermal images (Figs. 9-10).

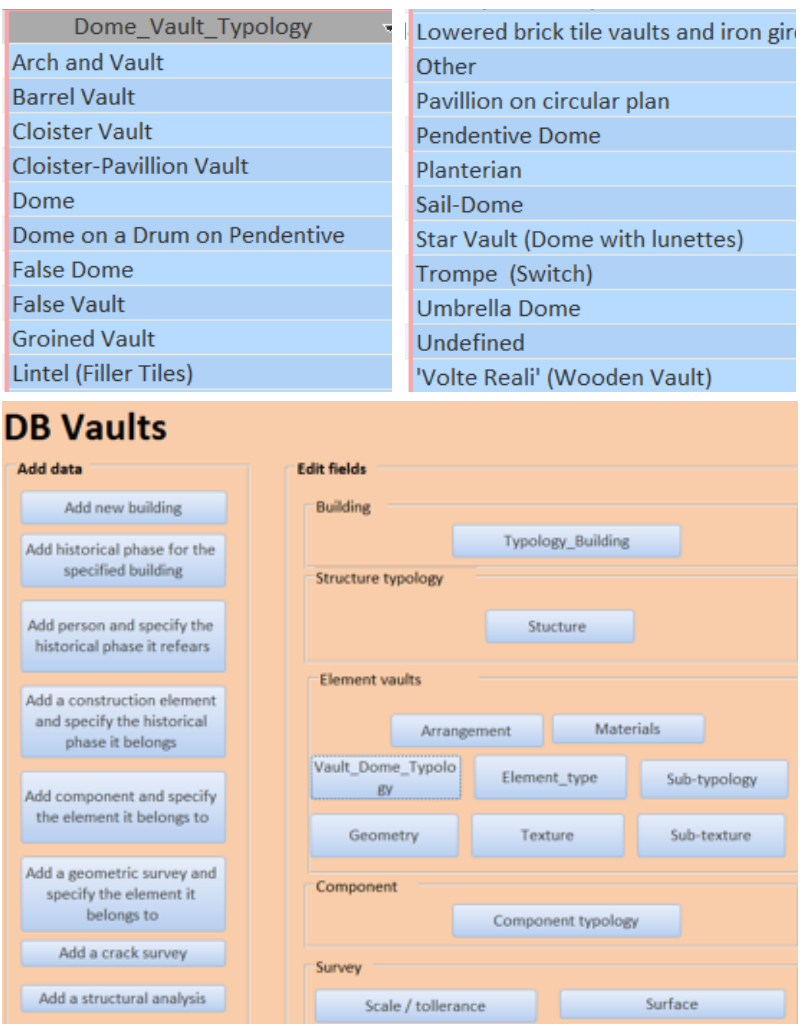

Figure 9. The semantic-based query of the Geo Database allows to cross relate different properties of each vaulted element across time and space 
Building

10_Bulihing Short Name $\quad$ Latitude Longitude country

Region (ttaty onit)

Madress

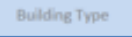

\begin{tabular}{|c|c|c|c|c|c|}
\hline 12 Pasy Monastery & 49,934673 & 13,39018 & Crech Republic & $\begin{array}{l}\text { Pleet (Region), Plreilskb, N.2 (Address), } \\
\text { Plasy (City) - } 33101 \text { (City Code) }\end{array}$ & Monsstery \\
\hline 13 Xlementinum Baroque Library & 50,086824 & 14,416042 & Crech Republic & $\begin{array}{l}\text { Prague (Region) 3porkova Mala } \\
\text { Strana, } 5 \text {, Prague (City), } 11000 \text { (City }\end{array}$ & Library \\
\hline 14 italim Cultural Institune & 50,087685 & 14,397616 & Crech Republic & $\begin{array}{l}\text { Prague(Region), Sporkova, Mals Strana } \\
\text { N335/14 (Address), Prague (City) } 11800\end{array}$ & Chapel \\
\hline
\end{tabular}

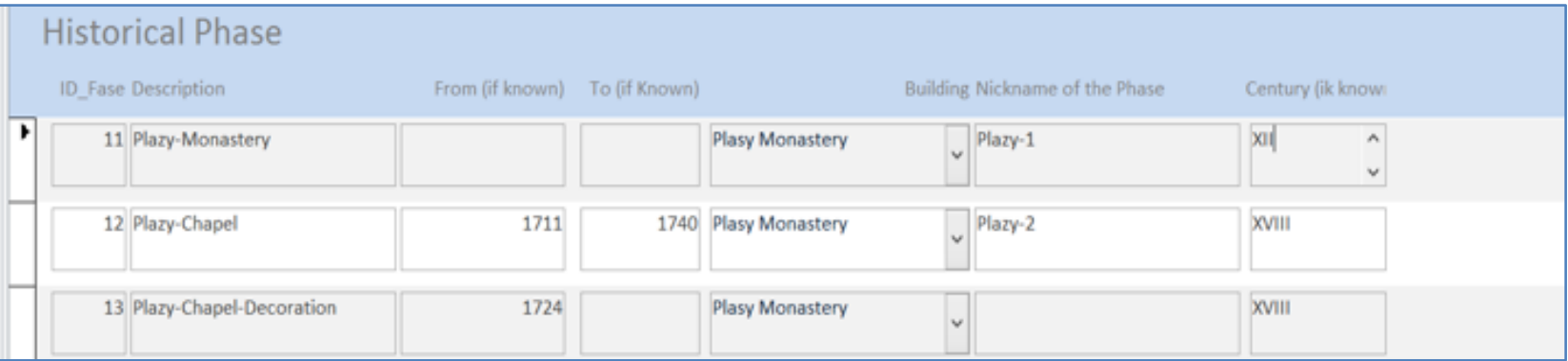

Figure 10. The Geo Database gathering the information acquired on the vaulted systems. In this case the Plasy Monastery Chapel star vault, together with the ones already processed (Klementinum Baroque Library and Italian Cultural Institute, both in Prague)

\section{CONCLUSION}

It is crucial for an owner or a researcher to define the purpose of their model at the beginning of the work. During the survey of the Plasy monastery, especially for Santini's masterpiece, St. Bernard's Chapel, the authors focused on the construction techniques of the vault in order to understand how it is really constructed without basing their assumptions only on its geometrical design.

This research is a first step into a wider analysis that starts from the 3D survey, goes to the 3D modeling, and ends in other specialized studies, e.g. historical or restoration analysis (Tucci et al., 2016). On the other hand, the monastery administrators deem the model relevant for touristic purposes: indeed they are working on reconstructing the building complex according to Santini's vision and the 3D model of the chapel allows them to digitally visualize the various colour schemes.

The future steps (laser scanning survey, thermal camera data acquisition) will be of vital importance in order to have a robust georeferenced data and to shed further light on the techniques that were used to ensure the shape of the vaults during construction. In particular, thermal camera would be useful to understand the brick arrangements of the ribs at the intrados.

Moreover, in the future the outputs from the shape analysis can be compared with the previous study that used the laser scanning data for the geometry description of the floorplan (Pavlík, 2008). Other analysis can be performed on the structural assessment. Further comparison with other similar vaulted systems (in Prague and in Italy), planned for the summer 2019, are expected to lead to new results.

\section{ACKNOWLEDGEMENTS}

The research has been supported by the institutional RVO: 68378297 in Czech Republic. The cooperation with the National Heritage Institute in Czech Republic is highly appreciated and the authors would like to thank the employees working in the Plasy Monastery for their enthusiastic approach to the research.

\section{REFERENCES}

Acierno, M., 2017. Processi di studio per il restauro e metodi digitali. In: Prescia R., eds., RICerca/REStauro Valorizzazione e gestione delle informazioni. Rome: Edizioni Quasar, pp. 838-848.
Amore, R., 2017. Beni culturali e nuove tecnologie. In: Prescia R., eds., RICerca/REStauro - Valorizzazione e gestione delle informazioni. Rome: Edizioni Quasar, pp. 849-856.

Artese, S., Lerma, J. L., Aznar Molla, J., Sánchez, R. M., Zinno, R., 2019. Integration of surveying techniques to detect the ideal shape of a dome: the case of the Escuela Pías church in Valencia. In: Int. Arch. Photogramm. Remote Sens. Spatial Inf. Sci., 42(2/W9), pp. 39-43.

Banfi, F., 2017. BIM orientation: grades of generation and information for different type of analysis and management process. In: Int. Arch. Photogramm. Remote Sens. Spatial Inf. Sci., 42(2/W5), pp. 57-64.

Banfi, F., Chow, L., Ortiz, M. R., Ouimet, C., Fai, S., : 2018. Building Information Modeling for Cultural Heritage: The Management of Generative Process for Complex Historical Buildings. In: Ioannides M., eds., Digital Cultural Heritage. Springer: Cham, pp. 119-130.

Banfi, F., 2019. Holistic generative modeling process for HBIM (Doctoral dissertation, Italy).

Barazzetti, L., Brovelli M. A., Scaioni, M., 2007. Problems related to the generation of true-orthomosaic with Lidar DDSMs. In: In: Int. Arch. Photogramm. Remote Sens. Spatial Inf. Sci., 36(3/W52), pp. 20-25.

Besl, P. J., McKay, N. D., 1992. Method for registration of 3-D shapes. In: Sensor Fusion IV: Control Paradigms and Data Structures, Vol. 1611, International Society for Optics and Photonics, pp. 586-607.

Boato, A., 2008. L'archeologia in architettura. Venice: Marsilio.

Brumana, R., Condoleo, P., Grimoldi, A., Banfi, F., Landi, A.G., Previtali, M., 2018a. HR LOD based HBIM to detect influences on geometry and shape by stereotomic construction techniques of brick vaults. In: Applied Geomatics 10, pp. 529543.

Brumana R., Condoleo P., Grimoldi A., Landi A.G, Attico d., T., Banfi F. and Previtali M., 2018b. HBIM feeding OpenAccess vault inventory through GeoDB HUB In: Ioannides M. et al., eds., Digital Heritage. Progress in Cultural 
Heritage: Documentation, Preservation, and Protection. Cham: Springer, pp. 27-38.

Brumana, R., Della Torre, S., Previtali, M., Barazzetti, L., Cantini, L., Oreni, D., Banfi, F., 2018c. Generative HBIM modeling to embody complexity (LOD, LOG, LOA, LOI): surveying, preservation, site intervention - the Basilica di Collemaggio (L’Aquila). In: Applied Geomatics, 10(4), pp. 545567.

Capone, M., Campi, M., Catuogno, R., 2015. Gothic churches in Paris. St. Gervais et St. Protais image matching $3 \mathrm{~d}$ reconstruction to understand the vaults system geometry. In: Int. Arch. Photogramm. Remote Sens. Spatial Inf. Sci, 40(5/W4), pp. 423-430.

Capone, M., Lanzara, E., 2019. Scan-to-BIM vs 3D ideal model HBIM: parametric tools to study domes geometry. . .

Della Torre, S., Mannoni, T., Pracchi, V., 1997. Magistri d'Europa. Como: Nodo Libri.

De Meyer, D., 1997. I Santini-Aichel: un caso di migrazione di architetti nella Praga barocca. In: Della Torre, S., Mannoni, T., Pracchi, V., eds., Magistri d'Europa. Como: Nodo Libri, pp. 237-248.

Etlin, R., A., 2015. The "strength of vaults". In: 5th International Congress on Construction History June 2015, Construction history society of America, Chicago, Illinois, pp. 49-60

Frič, P., Kotalík, J., Vávra, D., 2012. Drobné perly české architektury. Prague: Titanic, p. 308.

Guarini, G., 1737. Architettura Civile. Turin: Gianfrancesco Mairesse (Reprinting edited by Carbonieri, N., 1968. Architettura Civile. Milan: il Polifilo).

Grimoldi, A., 2005. Ricerca storica e diagnosi del degrado statico del patrimonio edilizio esistente. Il palazzo Cattaneo a Cremona. In: Aveta A., Casiello S., La Regina F., Picone R., eds., Restauro e consolidamento, Rome: Mancosu, pp. 215-220.

Horyna, M., 1998. Jan Blažej Santini-Aichel. Prague: Karolinum, p. 487.

Horyna, M., 2002. Elementi di ispirazione italiana nell'opera di Jan Blažej Santini-Aichel. In: La Nuova Rivista Italiana di Praga, 7(1), pp. 34-53.

Horyna, M. et al., 2008. Kostel sv. Jana Nepomuckého na Zelené hoře. Telč: Národní památkový ústav, p. 248.

Kalina, P., 2010. The Hybrid Architecture of Jan Blažej SantiniAichl and Patterns of Memory in Post-Reformation Bohemia. In: Uměni/Art, 58, pp. 42-56.

Lague, D., Brodu, N., Leroux, J., 2013. Accurate 3D comparison of complex topography with terrestrial laser scanner: application to the Rangitikei canyon (NZ). In: ISPRS, 82 , pp. $10-26$

López, F. J., Lerones, P. M., Llamas, J., Gómez-GarcíaBermejo, J., Zalama, E., A review of Heritage Building Information modeling (H-BIM). In: Multimodal Technologies Interact, 2(21).
Mazzetti, P., Latre, M. Á., Ernst, J., Brumana, R., Brauman, S., Nativi, S., 2015. Virtual hubs for facilitating access to open data. In: EGU General Assembly Conference, Vol. 17.

Mutschlechner, M. L., 1990. Imprese e maestranze lombarde nella Boemia del XVII secolo. In: Casciato M., Mornati S., Scavizzi P., eds., Il modo di costruire. Rome: Edilstampa.

Norberg-Schulz, C., 1968. Kilian Ignaz Dientzenhofer e il barocco boemo. Rome: Officina Edizioni.

Oreni, D., Brumana, R., Georgopoulos, A., Cuca, B., 2013. HBIM for conservation and management of built heritage: towards a library of vaults and wooden bean floors. In: Int. Arch. Photogramm. Remote Sens. Spatial Inf. Sci., 2(5/W1), pp. 215-221.

Pavelka, K., Řezníček, J., Bílá, Z., Pavlík, M., Kašička, F., 2017. Exaktni metody průzkumu památek. Prague: Česká technika.

Pavlík, M., 1997. Velká kapitula (Kaple sv. Benedikta) konventu v Plasech. In: Umění/Art, 45, pp. 530-538

Pavlík, M., 2008. Kaple sv. Bernarda (Malá kapitula) konventu v Plasech. In: Umění/Art, 56, pp. 446-448.

Pavlík, M., Pavelka, K., Řezníček, J., 2013. Zámecká kaple ve Smiřicích. In: Umění/Art, 61, pp. 23-32.

Škabrada, J., 2007. Konstrukce historických staveb. Prague: Argo, p. 395

Stanga, C., Hasníková, H., Brumana, R., Grimoldi, A., Banfi, F., 2019. Geometric primitives assessing Italian-Czech vault construction techniques in Baroque period. In: Int. Arch. Photogramm. Remote Sens. Spatial Inf. Sci Sciences, 42(2/W11), pp. 1081-1088.

Štíchová, R., 2008. Geometrie v architektuře Santiniho-Aichla. Thesis, Charles University, Prague.

Tucci, G., Bonora, V., Fiorini, L., Conti, A., 2016. The florence baptistery: 3-D Survey as a knowledge tool for historical and structural investigations. In: Int. Arch. Photogramm. Remote Sens. Spatial Inf. Sci, 41, pp. 977-984.

Tucci, G., Bonora, V., Conti, A., Fiorini, L., 2017. Digital workflow for the acquisition and elaboration of 3D data in a monumental complex: The fortress of saint john the baptist in Florence. In: Int. Arch. Photogramm. Remote Sens. Spatial Inf. Sci, 42 (2/W5), pp. 679-686.

Volk, R., Stengel, J., Schultmann, F., 2014. Building Information Modeling (BIM) for existing buildings - literature review and future needs. In: Automation in Construction, 38, pp. 109-127.

Zastoupil, J., Vidman, J., Hlavenka, P., 2011. Measured survey and digital photogrammetry methods during the restoration of the main dome decoration in the pilgrimage church of St. John of Nepomuk at Zelená Hora in Žd'ár nad sázavou. In: CIPA heritage documentation: Past Symposia - Available from: http://cipa.icomos.org/fileadmin/template/doc/PRAGUE/159.pd f. 